medicine and science related to human fertilisation and embryology. In an interim report the working group said that it "has yet to be satisfied that to undertake in vitro fertilisation with the sperm and the ova of a couple and to transfer the embryo to the uterus of another woman who might carry the embryo to term on behalf of the couple will ever be acceptable." In March 1984 the council approved a recommendation "that doctors should be advised that in consideration of the difficulties, anxieties, and uncertainties to all the individuals concerned, it considers that it is unethical for a doctor to become involved in the techniques and procedures to assist surrogate mothers. This statement does not affect the duty of care of the doctor to a woman who has conceived under these circumstances." The Warnock committee's report is imminent and is expected to offer authoritative guidance for the community as a whole on this complex issue.-ED, $B M \mathcal{A}$.

\section{Prison medical service}

SIR,-As the Governor of one of the overcrowded prisons (certified accommodation 570 , average population 1050) that $\mathrm{Dr} \mathrm{J} \mathrm{L}$ Gilgour refers to (26 May, p 1603), I would like to support him on a few matters that he raises and to expand on some crucial matters within the prison service.

Firstly, there are prisoners who are recognised as mentally abnormal and to whom a degree of psychiatric care and support would have been provided had they been in the community. Many of these prisoners are not in prison hospitals but in ordinary prisons and looked after by prison staff. These prisoners are easily manipulated and unpredictable, and in an overcrowded prison they can be extremely difficult to handle and the source of much disruption.

Secondly, as Dr Kilgour says, the lack of facilities in National Health Service hospitals is something which we have to work at. What is not recognised is that even when consultants agree to take our prisoners under the relevant Mental Health Act, it is often their own staff who will not agree to accept them, particularly when prisoners have shown violence in the past. It is not for me to criticise the health service staff but it is my duty to bring this matter to your notice. Without adequate facilities in the National Health Service prisons will go on containing men who should be "patients." Consequently, the courts will sentence mentally ill people to imprisonment who will then be released later on an unsuspecting public. One incident here recently caused an assault on a young woman within 24 hours of release.

Thirdly, to say that hospital officers are similar to medical orderlies in the Royal Army Medical Corps is not a fair comparison. Members of the Royal Army Medical Corps do not work 24 hours a day seven days a week with severely disordered and disruptive people in security surroundings; yet in war they may have a far more dangerous time. Hospital prison officers have great skill in dealing with personality disorders and mental illness, which is often recognised by visiting National Health Service specialists and trained nurses. The Royal College of Nursing should recognise the skills within the prison service, and I hope that through the British Medical fournal the medical profession will give the support that Dr Kilgour needs to obtain proper qualifications for his staff. Prison governors would be the first to support any recognition of hospital staff, and additionally the status of medical officers, often underrated and overworked like their colleagues outside. Because they are in a prison the quality of their work is not recognised.

There needs to be greater public awareness of the way society is pushing its disordered and disruptive, but hardly criminal, people away from the mental hospitals and into the prisons, with all its consequences; and the further need to recognise the skills and abilities of those staff who work so hard behind the wall.

\section{R J KENDRICK Governor}

HM Prison,

Winson Green,
Birmingham Bl8 4AS

\section{Risks of intrauterine contraceptive} devices

SIR, - Mr N Siddle is too categorical in saying that infections associated with the intrauterine contraceptive device result solely from organisms introduced at insertion or by ascent up the tail of the device (26 May, p 1554). Bloodborne infection is also possible. Over five years at one Birmingham hospital there were three cases of pneumococcal peritonitis in women using intrauterine contraceptive devices (one Gravigard, one Lippes loop, one Dalkon shield) but none in other women. ${ }^{1}$ Since only $6^{\circ} \%$ of women in the affected age group use an intrauterine contraceptive device, this points to a highly significant association between pneumococcal peritonitis and the intrauterine contraceptive device $(p=0.0002){ }^{2}$ Pneumococci have not been found in studies of the vaginal flora but commonly colonise the respiratory tract. ${ }^{3}$ One of the three patients had a concurrent pneumonia and another mitral stenosis, a condition which results in an increased incidence of chest infection. It thus seems highly likely that the pneumococci were blood borne from the respiratory tract to the uterus, the intrauterine contraceptive device providing a sanctuary from which they could then launch an invasion of the peritoneum.

Laboratoire de Bacteriologie,

LAURENCE GRUER

Hopital Cardiologique

France

' Gruer LD, Collingham KE, Edwards CW. Pneumococcal peritonitis associated with an IUCD. Lancet ccal perito 1983 ; ii 677 .

${ }^{2}$ Central Statistical Office. Use of contraceptives by age and marital status of women, 1976. Social Trends 1980;10:89.

Tashjian JH, Coulan CB, Washington JA. Vaginal fora in asymptomatic women. Mayo Clin Proc 1976;
$\mathbf{5 1}: 557-61$.

SIR,-In his leading article on the risks of intrauterine contraceptive devices (26 May, p 1554) Mr N Siddle states "increases in the rate of ectopic gestation [in intrauterine contraceptive device users] should probably be attributed to the sexual activity which leads to salpingitis rather than the intrauterine contraceptive device itself." This is not in accord with our experience in the Oxford-Family Planning Association contraceptive study. ${ }^{1}$

Up to the end of May 1984397 parous women in the Oxford-Family Planning Association contraceptive study had an unplanned pregnancy while using an intrauterine contraceptive device, a failure rate of 1.3 pregnancies per 100 woman years. Of these pregnancies 24 were extrauterine. During the same period 1228 parous women had an unplanned pregnancy while using combined oral contraceptives, a diaphragm, a condom, or no method of birth control. Of these pregnancies only four were extrauterine. Of the 24 women in whom an intrauterine device failure was followed by an ectopic pregnancy, none had a history of hospital referral (outpatient or inpatient) for any form of pelvic inflammatory disease. It is possible that some women had been treated for pelvic inflammation by their general practitioners, but the article on which $\mathrm{Mr}$ Siddle based his conclusions considered only salpingitis diagnosed at laparoscopy or at open operation. ${ }^{2}$

From the practical point of view the key points are: (a) around $5 \%$ of women experiencing an accidental pregnancy with an intrauterine device in situ will have an ectopic gestation, and $(b)$ the great majority of these women will not have an established history of pelvic inflammatory disease.

MELANIE LAWLESS

MARTIN VESSEY

Department of Community Medicine and

General Practice,

Radcliffe Infirmary, ' Vessey $M$, Doll $R$, Peto $R$, Johnson $B$, Wiggins $P$.
A long-term follow-up study of women using different methods of contraception. $\mathcal{f}$ Biosoc $S c i$ $1976 ; 8: 373-427$

Westrom L, Bengtsson LPH, Màrdh P-A. Incidence, trends and risks of ectopic pregnancy in a population of women. Br Med $\mathcal{J} 1981 ; 282: 15-8$.

\section{BMA and nuclear war}

SIR,-Like Dr R G Chapman and others (5 May, $p$ 1383), I was disappointed that the annual report of council contained such a minimal coverage on the progress of the board of science report The Medical Effects of Nuclear War.

The 1983 annual representative meeting (ARM) resolved that doctors participate as widely as possible in promoting the findings of the report, yet it appears that the British Medical Association has taken no action at all.

I hope that this year's ARM will remedy the current situation, in which the BMA is urging doctors to promote one of its publications without providing the means for them to do so.

Surely some small part of this year's $£ 2 \mathrm{~m}$ surplus could be allocated for provision of suitable promotional and educational material. A "Family Doctor" version of the report (for which I would not foresee any problems of advertiser support) would educate our patients on this topic. Is any other aspect of preventive medicine more urgent?

Alison Carroll

Birmingham B13 9UD

\section{GMC elections-why do doctors not} vote?

SIR,-Perhaps the reason why half the profession did not vote in the last General Medical Council elections was not the complexity of the single transferable vote system (2 June, p 1700), but the lack of information supplied about the candidates when we received the ballot form. How can one vote for somebody one knows nothing about?

Alas, the helpful British Medical Association insert about its candidates arrived too late. My ballot form had already irretrievably entered the waste paper system.

I am sure more doctors would vote if they received some information about all the candidates with the ballot form.

Next year I will wait for my British Medical Association insert to arrive.

London SE15 4AL 